\title{
Cost Comparison in 2015 Dollars for Radioisotope Power Systems-Cassini and Mars Science Laboratory
}

\author{
James E. Werner \\ Stephen G. Johnson \\ Carla C. Dwight \\ Kelly L. Lively \\ July 2016
}

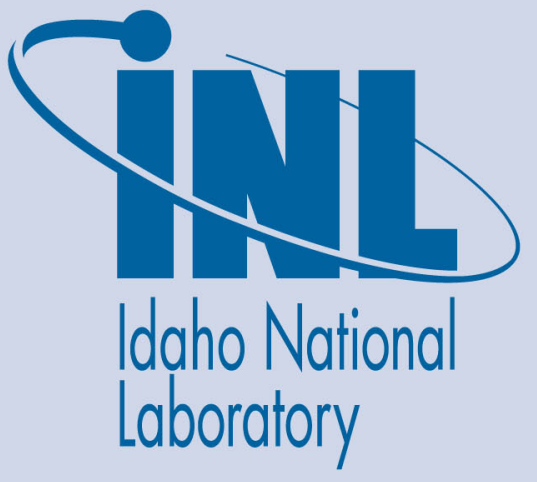

The INL is a U.S. Department of Energy National Laboratory operated by Battelle Energy Alliance 


\section{DISCLAIMER}

This information was prepared as an account of work sponsored by an agency of the U.S. Government. Neither the U.S. Government nor any agency thereof, nor any of their employees, makes any warranty, expressed or implied, or assumes any legal liability or responsibility for the accuracy, completeness, or usefulness, of any information, apparatus, product, or process disclosed, or represents that its use would not infringe privately owned rights. References herein to any specific commercial product, process, or service by trade name, trade mark, manufacturer, or otherwise, does not necessarily constitute or imply its endorsement, recommendation, or favoring by the U.S. Government or any agency thereof. The views and opinions of authors expressed herein do not necessarily state or reflect those of the U.S. Government or any agency thereof. 


\title{
Cost Comparison in 2015 Dollars for Radioisotope Power Systems-Cassini and Mars Science Laboratory
}

\author{
James E. Werner \\ Stephen G. Johnson \\ Carla C. Dwight \\ Kelly L. Lively
}

July 2016

Idaho National Laboratory

Space Nuclear Power and Isotope Technologies Division

Idaho Falls, Idaho 83415

http://www.inl.gov

Prepared for the

U.S. Department of Energy

Office of Nuclear Energy

Space and Defense Power Systems

Under DOE Idaho Operations Office

Contract DE-AC07-05ID14517 


\section{Executive Summary}

Radioisotope power systems (RPSs) have enabled missions requiring reliable, long-lasting power in remote, harsh environments such as space since the early 1960s. Costs for RPSs are high, but are often misrepresented due to the complexity of space missions and inconsistent charging practices among the many and changing participant organizations over the years. This paper examines historical documentation associated with two past successful flight missions, each with a different RPS design, to provide a realistic cost basis for RPS production and deployment. The missions and their respective RPSs are Cassini, launched in 1997, that uses the general purpose heat source (GPHS) radioisotope thermoelectric generator (RTG), and Mars Science Laboratory (MSL), launched in 2011, that uses the multi-mission RTG (MMRTG). Actual costs in their respective years are discussed for each of the two RTG designs and the missions they enabled, and then present day values to 2015 are computed to compare the costs.

Costs for this analysis were categorized into two areas: development of the specific RTG technology, and production and deployment of an RTG. This latter category includes material costs for the flight components (including Pu-238 and fine weave pierced fabric (FWPF)); manufacturing of flight components; assembly, testing, and transport of the flight RTG(s); ground operations involving the RTG(s) through launch; nuclear safety analyses for the launch and for the facilities housing the RTG(s) during all phases of ground operations; DOE's support for NEPA analyses; and radiological contingency planning. This analysis results in a fairly similar 2015 normalized cost for the production and deployment of an RTGapproximately $\$ 118 \mathrm{M}$ for the GPHS-RTG and \$109M for the MMRTG.

In addition to these two successful flight missions, the costs for development of the MMRTG are included to serve as a future reference. Note that development costs included herein for the MMRTG do not include costs from NASA staff or facilities for their development efforts-they only include the amounts costed by DOE and DOE contractors. The 2015 value for MMRTG development is $\$ 83 \mathrm{M}$.

Both of the RPS types analyzed herein use the general purpose heat source (GPHS) module as the "heart of the RPS." The estimates presented herein do not include development costs for the GPHS. These estimates also do not include the RPS infrastructure cost to maintain the facilities, equipment, and personnel necessary to enable the production of RPSs, except to the extent that the infrastructure is utilized during the production campaigns to provide RPSs for missions. It was not until after the Cassini mission that an RPS infrastructure funding structure was defined and funded separately from mission-specific elements.

The information presented herein could allow for more accurate budget planning estimates for space missions being considered over the next decade and beyond. 


\section{Purpose}

Radioisotope power systems (RPSs) have enabled missions requiring reliable, long-lasting power in remote, harsh environments such as space since the early 1960s. Costs for RPSs are high, but are often misrepresented due to the complexity of space missions and inconsistent charging practices among the many and changing participant organizations over the years. This paper examines historical documentation associated with two past successful flight missions, each with a different RPS design, to provide a realistic cost basis for RPS production and deployment. The missions and their respective RPSs are Cassini, launched in 1997, that uses the general purpose heat source (GPHS) radioisotope thermoelectric generator (RTG), and Mars Science Laboratory (MSL), launched in 2011, that uses the multi-mission RTG (MMRTG). Actual costs in their respective years are discussed for each of the two RTG designs and the missions they enabled, and then present day values to 2015 are computed to compare the costs. In addition to these two successful flight missions, the costs for development of the MMRTG are included to serve as a future reference. The information presented herein could allow for more accurate budget planning estimates for space missions being considered over the next decade and beyond.

\section{Mission and RPS Background}

Summary information about the Cassini and MSL flight missions and their RTGs is provided in Table 1 to compare features of these two successful projects. Note that for the remainder of this paper, an unfueled flight generator is referred to as an ETG (electrically-heated thermoelectric generator), and once it is fueled with the Pu-238 heat source modules, it is referred to as a flight RTG. Each are numbered sequentially as they are built, e.g., E1, F1, E2, F2, etc.

The Cassini GPHS-RTG project was initiated by the General Electric Company - Aerospace (GE) in 1991 under Department of Energy (DOE) contract DE-AC03-91 SF1 8852, entitled "General Purpose Heat Source Radioisotope Thermoelectric Generator (GPHS-RTG) for the Comet Rendezvous Asteroid Flyby (CRAF)/Cassini RTG Program." As a result of business transactions during the period of this contract, GE Aerospace became Martin Marietta Aerospace in 1993. In 1995 Martin Marietta became part of Lockheed Martin. The DOE and these contractors delivered three FU GPHS-RTGs (F2, F6, and F7), various ETG bodies and parts, plus 157 light weight radioisotope heater units (LWRHUs). Also, F5 that had been produced as a spare for the earlier Galileo and Ulysses missions but not needed, was maintained as a spare for Cassini. E2 had also been produced during the Galileo and Ulysses campaigns. Parts of E8 had been produced as part of the Cassini mission, and were later used for the Pluto New Horizons mission that launched in 2006. Production of flight hardware and fuel began during 1990 and the completed RTGs were delivered to KSC in May 1997. (References 1 and 2)

The newest RTG designed in the 2003-2007 timeframe, called a Multi-Mission Radioisotope Thermoelectric Generator (MMRTG), was designed to operate on a planet's surface and in the vacuum of space. The MMRTG has a flexible modular design capable of meeting the needs of a wide variety of missions. The design goals for the MMRTG included optimizing power levels over a minimum lifetime of 14 years and ensuring a high degree of safety. The MMRTG project was initiated by Boeing in 2003 under DOE contract DE-AC07-03SF22307, entitled "Multi-Mission Radioisotope Thermoelectric Generator (MMRTG)." As a result of several business transactions between 2003 and 2013, Boeing eventually became AerojetRocketdyne which now has the MMRTG contract for DOE. (References 1 and 2) 


\begin{tabular}{|c|c|c|}
\hline FEATURE & CASSINI GPHS-RTG & MSL MMRTG \\
\hline RTG Description & $\begin{array}{l}\text { - } 18 \text { modules, each containing } 4 \text { fueled } \\
\text { clads (FC) = 72 FC per RTG } \\
\text { - Each FC contains approximately } 110 \\
\text { grams (g) Pu-238 } \\
\text { - } 3 \text { RTG on spacecraft = } 54 \text { modules }=216 \\
\text { FCs = } 23.8 \text { kg Pu-238 in } 3 \text { GPHS-RTGs } \\
\text { - Silicon-germanium unicouples } \\
\text { - Internal cavity not sealed }\end{array}$ & $\begin{array}{l}\text { - } 8 \text { modules, each containing } 4 \mathrm{FC}=32 \\
\text { FC per RTG = } 3.5 \mathrm{~kg} \text { Pu-238 per } \\
\text { MMRTG } \\
\text { - Each FC contains approximately } 110 \\
\text { grams (g) Pu-238 } \\
\text { - } 1 \text { RTG on rover } \\
\text { - Lead-telluride thermoelectrics } \\
\text { - Internal cavity sealed during } \\
\text { assembly to protect against } \\
\text { atmosphere on planet }\end{array}$ \\
\hline $\begin{array}{l}\text { Beginning of } \\
\text { Mission Power } \\
\left(\text { BOM), } \mathrm{W}_{\mathrm{e}}\right.\end{array}$ & $\begin{array}{l}\text { - } 285 \mathrm{~W}_{\mathrm{e}} \text { per GPHS-RTG } \\
\text { - (855 We for } 3 \text { GPHS-RTGs on Cassini) }\end{array}$ & - $110 \mathrm{~W}_{\mathrm{e}}$ for MMRTG \\
\hline $\begin{array}{l}\text { RTG } \\
\text { Development }\end{array}$ & $\begin{array}{l}\text { - Development took place in the late } \\
\text { 1970s through mid-1980s, by many } \\
\text { different organizations. } \\
\text { - GPHS-RTGs were first used on Galileo } \\
\text { and Ulysses missions launched in } 1989 \\
\text { and 1990, respectively, and then for the } \\
\text { Cassini and Pluto New Horizons } \\
\text { missions launched in } 1997 \text { and 2006, } \\
\text { respectively. }\end{array}$ & $\begin{array}{l}\text { - Development began in } 2003 \\
\text { - First used on MSL mission }\end{array}$ \\
\hline $\begin{array}{l}\text { RTG Assembly } \\
\text { and Testing; } \\
\text { Transport; and } \\
\text { Ground } \\
\text { Operations } \\
\text { Support at } \\
\text { Kennedy Space } \\
\text { Center (KSC) }\end{array}$ & $\begin{array}{l}\text { - FCs were fabricated at Los Alamos } \\
\text { National Laboratory (LANL) } \\
\text { - RTGs were assembled and tested at the } \\
\text { Mound facility in Ohio in 1996-1997, } \\
\text { and transported to KSC in summer } 1997\end{array}$ & $\begin{array}{l}\text { - FCs were fabricated at LANL } \\
\text { - MMRTG was fueled and tested at } \\
\text { Idaho National Laboratory (INL) in } \\
\text { late } 2008 \text { and early 2009; launch was } \\
\text { delayed for } 2 \text { years after the } \\
\text { MMRTG was assembled, so the unit } \\
\text { was stored at INL until it was } \\
\text { transported to KSC in mid-2011. }\end{array}$ \\
\hline Launch & $\begin{array}{l}\text { - Launched October 15, } 1997 \\
\text { - Titan IV-B launch vehicle }\end{array}$ & $\begin{array}{l}\text { - Launched November 26, } 2011 \\
\text { - Atlas V } 551 \text { launch vehicle }\end{array}$ \\
\hline $\begin{array}{l}\text { Mission } \\
\text { Description }\end{array}$ & $\begin{array}{l}\text { - Cassini spacecraft successfully explored } \\
\text { Venus, Jupiter, and continues to } \\
\text { explore Saturn }\end{array}$ & $\begin{array}{l}\text { - MSL's Curiosity rover successfully } \\
\text { landed on Mars August 6, 2012, and } \\
\text { continues to explore the Martian } \\
\text { surface today. }\end{array}$ \\
\hline
\end{tabular}




\section{Cost Studies}

RTG cost information from a variety of sources is presented and analyzed in Tables 2 and 3, respectfully, for the Cassini and MSL flight missions. Explanations, key assumptions, and references for the estimated costs are included in notes following each table. The actual year costs are then escalated to account for inflation through 2015. The escalation factors used are listed in Table 4, along with the total cost for each project area analyzed, the escalated cumulative costs through 2015, and the calculated 2015 value for production and deployment of a single RPS. Also included is the calculated cost per $W_{e}$ at BOM for the GPHS-RTG and the MMRTG using the estimated costs herein. 
Table 2, Cassini GPHS-RTG Cost Estimate

\begin{tabular}{|c|c|c|c|c|c|c|c|c|c|c|}
\hline \multirow[b]{2}{*}{ Cost Element / Organization } & \multicolumn{10}{|c|}{ \$K in Year Shown (a) } \\
\hline & FY1990 & FY1991 & FY1992 & FY1993 & FY1994 & FY1995 & FY1996 & FY1997 & FY1998 & $\begin{array}{c}\text { Total FY1990- } \\
1998 \\
\end{array}$ \\
\hline $\begin{array}{l}\text { Total Cost for Production of Cassini RTGs per NASA/DOE } \\
\text { MOU Supplement Agreement No. } 1 \text { (1993) (b ) }\end{array}$ & $\$ 4,600$ & $\$ 43,000$ & $\$ 45,600$ & $\$ 42,700$ & $\$ 43,700$ & $\$ 36,200$ & $\$ 24,000$ & $\$ 15,100$ & $\$ 3,100$ & $\$ 258,000$ \\
\hline DOE Funding & $\$ 4,100$ & $\$ 24,100$ & $\$ 25,600$ & $\$ 20,400$ & $\$ 20,000$ & $\$ 19,000$ & $\$ 15,500$ & $\$ 10,500$ & $\$ 2,500$ & $\$ 141,700$ \\
\hline NASA Funding to DOE & $\$ 500$ & $\$ 18,900$ & $\$ 20,000$ & $\$ 22,300$ & $\$ 23,700$ & $\$ 17,200$ & $\$ 8,500$ & $\$ 4,600$ & $\$ 600$ & $\$ 116,300$ \\
\hline Additional Cost for Pu-238 $=\$ 46.3 \mathrm{M}$ (c) & $\$ 0$ & $\$ 0$ & $\$ 0$ & $\$ 0$ & $\$ 0$ & $\$ 0$ & $\$ 0$ & $\$ 46,300$ & & $\$ 46,300$ \\
\hline $\begin{array}{l}\text { Less Cost to Move FC manufacturing from SRS to LANL } \\
\text { (e) }\end{array}$ & & & $-\$ 16,000$ & $-\$ 16,000$ & $-\$ 16,000$ & & & & & $-\$ 48,000$ \\
\hline Less Fuel Clad Safety Testing (d) & & & & $-\$ 10,000$ & $-\$ 10,000$ & $-\$ 20,000$ & & & & $-\$ 40,000$ \\
\hline $\begin{array}{l}\text { Less Cost of FWPF Billets Beyond Those Required for } \\
\text { Cassini (f) }\end{array}$ & & & & $-\$ 1,736$ & & & & & & $-\$ 1,736$ \\
\hline $\begin{array}{l}\text { ADJUSTED TOTAL COST FOR PRODUCTION OF } \\
\text { CASSINI RTGS }\end{array}$ & $\$ 4,600$ & $\$ 43,000$ & $\$ 29,600$ & $\$ 14,964$ & $\$ 17,700$ & $\$ 16,200$ & $\$ 24,000$ & $\$ 61,400$ & $\$ 3,100$ & $\$ 214,564$ \\
\hline
\end{tabular}

\section{NOTES for Table 2:}

(a) Various sources of information (References 3, 4, and 5) provide some elements of cost for the Cassini RTGs, however, no single source or the combination of sources provide a comprehensive breakdown by function and by funding agency (DOE or NASA) over the course of the entire RTG production, delivery, and integration campaign.

(b) Per Reference 6, this total cost estimate, broken down into NASA and DOE contributions by fiscal year, includes the costs to manufacture the FCs and Electrically-heated Thermoelectric Generators (ETGs), to assemble and test the RTGs, and to deliver the RTGs to Kennedy Space Center (KSC) and to provide integration support through launch. It does not include the costs for the 157 Light Weight Radioisotope Heater Units (LWRHU) also produced and delivered for the Cassini mission-these costs are shown separately in Reference 6 at a total of $\$ 6.56 \mathrm{M}$. (Of these 157 LWRHUs produced, 117 were actually used on Cassini, and 40 were placed in inventory for future missions.) Reference 6 also notes that the cost for the Pu-238 is not included. See note (c) for discussion of the Pu-238 cost.

(c) Pu-238 cost was obtained from 1997 Office of Inspector General Report on the Cassini Mission (Reference 4), which estimated the total Pu-238 cost as $\$ 46.3 \mathrm{M}$, based on “\$1,968 per gram" for the total of 23,503 grams of fuel used in the Cassini systems. This amount was added to the Cassini cost estimate in 1997 for this analysis. 
(d) As described in Reference 2, FC manufacturing operations were moved from SRS to LANL in 1993-95. The associated costs were estimated per Reference 7, and were removed from the Cassini cost for this analysis. Very little equipment was actually moved from SRS to LANL; the majority of the cost was standing up the capability at LANL.

(e) FC safety test information was obtained from Reference 8. This cost (\$40M) is removed for this analysis, as it is considered part of transfer costs for this analysis since the tests were used to confirm that LANL could produce the same FCs as SRS, not for the production of RPSs for Cassini.

(f) Per Reference 9, 48 billets of fine weave pierced fabric (FWPF) were procured in 1992-93. Approximately 3 sets of "step 0" (Reference 2) module components can be made from 1 billet, so this equates to approximately 144 step 0 modules from this procurement. Fifty-four modules plus a few spares were needed for Cassini ( $38 \%$ ), so only $38 \%$ of the billet procurement cost is included in the Cassini RTG production estimate for this analysis. 
Table 3, MSL MMRTG Cost Estimate

\begin{tabular}{|c|c|c|c|c|c|c|c|c|c|c|c|}
\hline \multirow[b]{2}{*}{ Cost Element / Organization } & \multicolumn{11}{|c|}{ \$K in Year Shown (a) } \\
\hline & $\begin{array}{l}\text { FY } \\
2003\end{array}$ & $\begin{array}{c}\text { FY } \\
2004\end{array}$ & $\begin{array}{c}\text { FY } \\
2005\end{array}$ & $\begin{array}{c}\text { FY } \\
2006\end{array}$ & $\begin{array}{l}\text { FY } \\
2007\end{array}$ & $\begin{array}{l}\text { FY } \\
2008\end{array}$ & $\begin{array}{l}\text { FY } \\
2009\end{array}$ & $\begin{array}{l}\text { FY } \\
2010\end{array}$ & $\begin{array}{l}\text { FY } \\
2011\end{array}$ & $\begin{array}{l}\text { FY } \\
2012\end{array}$ & $\begin{array}{c}\text { Total FY } 2002 \\
2014\end{array}$ \\
\hline $\begin{array}{l}\text { Design, fabrication and testing of an } \\
\text { unfueled engineering unit and } \\
\text { qualification unit (QU) (Rocketdyne) }\end{array}$ & $\$ 1,835$ & $\$ 17,870$ & $\$ 18,626$ & $\$ 15,988$ & $\$ 8,750$ & $\$ 2,699$ & $\$ 649$ & $\$ 224$ & $\$ 190$ & $\$ 17$ & $\$ 66,847$ \\
\hline DEVELOPMENT SUBTOTAL & $\$ 1,835$ & $\$ 17,870$ & $\$ 18,626$ & $\$ 15,988$ & $\$ 8,750$ & $\$ 2,699$ & $\$ 649$ & $\$ 224$ & $\$ 190$ & $\$ 17$ & $\$ 66,847$ \\
\hline $\begin{array}{l}\text { MMRTG E1 Complete Fabrication, E2 \& } \\
\text { E3 Initial Fabrication, Support to F1 } \\
\text { Assembly, Testing, and Ground } \\
\text { Operations (Rocketdyne) (b) }\end{array}$ & $\$ 0$ & $\$ 0$ & $\$ 0$ & $\$ 0$ & $\$ 5,605$ & $\$ 9,190$ & $\$ 3,700$ & $\$ 4,630$ & $\$ 3,268$ & $\$ 508$ & $\$ 26,902$ \\
\hline $\begin{array}{l}\text { CBCF and Iridium Fabrication, Safety } \\
\text { Test Support (ORNL) }\end{array}$ & $\$ 195$ & $\$ 0$ & $\$ 361$ & $\$ 0$ & $\$ 0$ & $\$ 0$ & $\$ 0$ & $\$ 0$ & $\$ 0$ & $\$ 0$ & $\$ 556$ \\
\hline FC Manufacturing (LANL) & $\$ 2,000$ & $\$ 2,000$ & $\$ 1,000$ & $\$ 1,000$ & $\$ 1,000$ & $\$ 1,000$ & $\$ 1,000$ & $\$ 1,000$ & $\$ 0$ & $\$ 0$ & $\$ 10,000$ \\
\hline $\begin{array}{l}\text { F1 MMRTG Assembly, Testing, } \\
\text { Transport, Groud Operations (INL) }\end{array}$ & $\$ 0$ & $\$ 2,268$ & $\$ 1,236$ & $\$ 4,217$ & $\$ 5,925$ & $\$ 5,850$ & $\$ 3,714$ & $\$ 0$ & $\$ 2,233$ & $\$ 1,408$ & $\$ 26,851$ \\
\hline $\begin{array}{l}\text { QA and Risk Oversight (Washington } \\
\text { Safety Management Solutions (WSMS)) }\end{array}$ & $\$ 0$ & $\$ 0$ & $\$ 0$ & $\$ 0$ & $\$ 100$ & $\$ 200$ & $\$ 200$ & $\$ 100$ & $\$ 400$ & $\$ 500$ & $\$ 1,500$ \\
\hline NEPA and Launch Safety (SNL) & & & & $\$ 2,940$ & $\$ 2,710$ & $\$ 3,600$ & $\$ 2,000$ & $\$ 600$ & $\$ 300$ & & $\$ 12,150$ \\
\hline \begin{tabular}{|l} 
Radiological Contingency Planning \\
(Various)
\end{tabular} & $\$ 0$ & $\$ 0$ & $\$ 900$ & $\$ 900$ & $\$ 900$ & $\$ 1,000$ & $\$ 1,100$ & $\$ 1,100$ & $\$ 1,100$ & & $\$ 7,000$ \\
\hline DOE Travel & $\$ 15$ & $\$ 15$ & $\$ 15$ & $\$ 15$ & $\$ 15$ & $\$ 15$ & $\$ 15$ & $\$ 15$ & $\$ 15$ & $\$ 15$ & $\$ 150$ \\
\hline $\mathrm{Pu}-238$ (c) & $\$ 0$ & $\$ 0$ & $\$ 0$ & $\$ 8,560$ & $\$ 0$ & $\$ 0$ & $\$ 0$ & $\$ 0$ & $\$ 0$ & $\$ 0$ & $\$ 8,560$ \\
\hline FWPF (d) & $\$ 0$ & $\$ 0$ & $\$ 0$ & $\$ 326$ & $\$ 0$ & $\$ 0$ & $\$ 0$ & $\$ 0$ & $\$ 0$ & $\$ 0$ & $\$ 326$ \\
\hline $\begin{array}{l}\text { MSL MMRTG F1 FABRICATION, } \\
\text { FUELING, TESTING, DELIVERY, } \\
\text { GROUND OERATIONS SUBTOTAL } \\
\end{array}$ & $\$ 2,210$ & $\$ 4,283$ & $\$ 3,512$ & $\$ 17,958$ & $\$ 16,255$ & $\$ 20,855$ & $\$ 11,729$ & $\$ 7,445$ & $\$ 7,316$ & $\$ 2,431$ & $\$ 93,995$ \\
\hline
\end{tabular}




\section{NOTES for Table 3:}

(a) Except as otherwise noted, the cost information in this table was provided via personal communications between the authors and DOE or DOE contractor personnel (References 7-12).

(b) Per Reference 1, an additional \$9.3M was spent in FY2012 - 2014 under the Rocketdyne MMRTG contract for followon preparations towards flight readiness of E2 and E3. These costs are excluded from this analysis.

(c) Cost for Pu-238 shown is based on the same rate per gram as noted in the 1997 Cassini OIG report (Reference $\mathrm{x}$ ), but escalated to 2006 using the same escalation factors as shown in Table 4 in order to be consistent with the Cassini analysis.

(d) Cost for FWPF used in this analysis is based on the cost for the billet order made in 1993 to support Cassini and future missions. For MSL, 9 "step 2" (Reference 1) modules were used (approximately 2.5 step 2 modules can be made from each FWPF billet, so 4 billets were assumed), representing approximately $8 \%$ of the 1993 order (48 billets that cost $\$ 2.8 \mathrm{M}$ then), so $8 \%$ of this amount escalated to 2006 is the basis for the cost shown herein. 
Table 4 Summary Cost Estimates in 2015 Dollars (Page 1 of 2)

\begin{tabular}{|c|c|c|c|c|c|c|c|c|c|c|c|c|c|c|c|c|c|c|}
\hline & $\mathrm{A}$ & $B$ & C & $D$ & $E$ & $F$ & G & $\mathrm{H}$ & 1 & \rfloor & $\mathrm{K}$ & $L$ & $\mathrm{M}$ & $\mathrm{N}$ & 0 & $P$ & $Q$ & $R$ \\
\hline 6 & \multirow{4}{*}{ Cost Element } & FY & 1990 & 1991 & 1992 & 1993 & 1994 & 1995 & 1996 & 1997 & 1998 & 1999 & 2000 & 2001 & 2002 & 2003 & 2004 & 2005 \\
\hline 7 & & \begin{tabular}{|c||} 
Inflation \\
$\%$ (a) \\
\end{tabular} & 0 & 0.042 & 0.030 & 0.03 & 0.026 & 0.028 & 0.03 & 0.023 & 0.016 & 0.022 & 0.034 & 0.028 & 0.016 & 0.023 & 0.027 & 0.034 \\
\hline 8 & & \begin{tabular}{|c||} 
Inflation \\
Factor
\end{tabular} & 0 & 1.042 & 1.03 & 1.03 & 1.026 & 1.028 & 1.03 & 1.023 & 1.016 & 1.022 & 1.034 & 1.028 & 1.016 & 1.023 & 1.027 & 1.034 \\
\hline 9 & & $\begin{array}{c}\text { Sum } \\
\text { (Actual } \\
\text { Year) } \\
\end{array}$ & & \multicolumn{12}{|c|}{$\begin{array}{l}\text { Each cost element shows the values in actual years in the top row, followed by the cumulative escalated values in the next row in } 2015 \\
\text { \$K based on the escalation factors listed above. }\end{array}$} & & & \\
\hline 10 & Cassini & $\$ 214,564$ & $\$ 4,600$ & $\$ 43,000$ & $\$ 29,600$ & $\$ 14,964$ & $\$ 17,700$ & $\$ 16,200$ & $\$ 24,000$ & $\$ 61,400$ & $\$ 3,100$ & & & & & & & \\
\hline 11 & \begin{tabular}{|l} 
Cassini Escalated to \\
2015 (cum)
\end{tabular} & & $\$ 4,600$ & $\$ 49,599$ & $\$ 81,575$ & $\$ 99,435$ & $\$ 120,181$ & $\$ 140,200$ & $\$ 169,126$ & \begin{tabular}{|l|}
$\$ 235,828$ \\
\end{tabular} & $\$ 242,750$ & $\$ 248,091$ & $\$ 256,526$ & $\$ 263,709$ & $\$ 267,928$ & $\$ 274,090$ & $\$ 281,491$ & $\$ 291,062$ \\
\hline 12 & MMRTG Development & $\$ 66,847$ & & & & & & & & & & & & & & $\$ 1,835$ & $\$ 17,870$ & $\$ 18,626$ \\
\hline 13 & $\begin{array}{l}\text { MMRTG Development } \\
\text { Escalated to } 2015 \text { Cum }\end{array}$ & & & & & & & & & & & & & & & $\$ 1,835$ & $\$ 20,237$ & $\$ 40,184$ \\
\hline 14 & MMRTG Production & $\$ 93,995$ & & & & & & & & & & & & & & $\$ 2,210$ & $\$ 4,283$ & $\$ 3,512$ \\
\hline 15 & \begin{tabular}{|l|l} 
MMRTG Production \\
Escalated to 2015 Cum
\end{tabular} & & & & & & & & & & & & & & & $\$ 2,210$ & $\$ 6,668$ & $\$ 10,526$ \\
\hline 16 & ASRG Development & $\$ 188,228$ & & & & & & & & & & & & & $\$ 7,176$ & $\$ 9,783$ & $\$ 5,842$ & $\$ 8,420$ \\
\hline 17 & ASRG Development & & & & & & & & & & & & & & $\$ 7,176$ & $\$ 17,349$ & $\$ 23,817$ & $\$ 33,334$ \\
\hline
\end{tabular}


Table 4 Cost Estimates in 2015 Dollars (Page 2 of 2)

\begin{tabular}{|c|c|c|c|c|c|c|c|c|c|c|c|c|c|c|c|c|}
\hline & A & $B$ & $\mathrm{~s}$ & $T$ & $U$ & $\mathrm{~V}$ & $\mathrm{~W}$ & $x$ & $Y$ & $z$ & AA & $A B$ & $A C$ & $A D$ & $\mathrm{AE}$ & $\mathrm{AF}$ \\
\hline 6 & \multirow{4}{*}{ Cost Element } & FY & 2006 & 2007 & 2008 & 2009 & 2010 & 2011 & 2012 & 2013 & 2014 & 2015 & \multirow{5}{*}{$\begin{array}{c}\text { Sum in } \\
2015 \text { \$K }\end{array}$} & \multirow{5}{*}{$\begin{array}{c}\text { Cost of } \\
\text { Escalation } \\
(2015 \$ K)\end{array}$} & \multirow{4}{*}{$\begin{array}{l}\text { Cost Per Unit } \\
(2015 \$ K)\end{array}$} & \multirow{4}{*}{$\begin{array}{l}\text { Cost Per } \\
\text { BOM We } \\
(2015 \$ K)\end{array}$} \\
\hline 7 & & $\begin{array}{c}\text { Inflation } \\
\%(a) \\
\end{array}$ & 0.032 & 0.028 & 0.038 & -0.004 & 0.016 & 0.032 & 0.021 & 0.015 & 0.016 & 0.001 & & & & \\
\hline 8 & & \begin{tabular}{c|} 
Inflation \\
Factor \\
\end{tabular} & 1.032 & 1.028 & 1.038 & 0.996 & 1.016 & 1.032 & 1.021 & 1.015 & 1.016 & 1.001 & & & & \\
\hline 9 & & $\begin{array}{c}\text { Sum } \\
\text { (Actual } \\
\text { Year) }\end{array}$ & & \multicolumn{9}{|c|}{$\begin{array}{l}\text { Each cost element shows the values in actual years in the top row, followed by the cumulative } \\
\text { escalated values in the next row in } 2015 \$ K \text { based on the escalation factors listed above. }\end{array}$} & & & & \\
\hline 10 & Cassini & $\$ 214,564$ & & & & & & & & & & & & & & \\
\hline 11 & $\begin{array}{l}\text { Cassini Escalated to } \\
2015 \text { (cum) }\end{array}$ & & $\$ 300,376$ & $\$ 308,786$ & $\$ 320,520$ & $\$ 319,238$ & $\$ 324,346$ & $\$ 334,725$ & $\$ 341,754$ & $\$ 346,880$ & $\$ 352,430$ & $\$ 352,783 \mid$ & $\$ 352,783$ & $\$ 138,219$ & $\$ 117,594$ & $\$ 413$ \\
\hline 12 & MMRTG Development & $\$ 66,847$ & $\$ 15,988$ & $\$ 8,750$ & $\$ 2,699$ & $\$ 649$ & $\$ 224$ & $\$ 190$ & $\$ 17$ & & & & & & & \\
\hline 13 & $\begin{array}{l}\text { MMRTG Development } \\
\text { Escalated to } 2015 \text { Cum }\end{array}$ & & $\$ 57,969$ & $\$ 68,587$ & $\$ 73,996$ & $\$ 74,346$ & $\$ 75,763$ & $\$ 78,383$ & $\$ 80,046$ & $\$ 81,247$ & $\$ 82,547$ & $\$ 82,630$ & $\$ 82,630$ & $\$ 15,783$ & & \\
\hline 14 & MMRTG Production & $\$ 93,995$ & $\$ 17,958$ & $\$ 16,255$ & $\$ 20,855$ & $\$ 11,729$ & $\$ 7,445$ & $\$ 7,316$ & $\$ 2,431$ & & & & & & & \\
\hline 15 & $\begin{array}{l}\text { MMRTG Production } \\
\text { Escalated to } 2015 \text { Cum }\end{array}$ & & $\$ 29,395$ & $\$ 46,929$ & $\$ 70,360$ & $\$ 81,761$ & $\$ 90,633$ & $\$ 101,083$ & $\$ 105,689$ & $\$ 107,274$ & $\$ 108,990$ & $\$ 109,099$ & $\$ 109,099$ & $\$ 15,105$ & $\$ 109,099$ & $\$ 992$ \\
\hline 16 & ASRG Development & $\$ 188,228$ & $\$ 8,241$ & $\$ 10$ & $\$ 7,276$ & $\$ 12,368$ & $\$ 14,013$ & $\$ 33,794$ & $\begin{array}{l}43,869 \\
\end{array}$ & \begin{tabular}{|l|}
$\$ 37,435$ \\
\end{tabular} & & & & & & \\
\hline 17 & \begin{tabular}{|l} 
ASRG Development \\
Escalated to 2015 Cum
\end{tabular} & & $\$ 42,905$ & $\$ 44,117$ & $\$ 53,346$ & $\$ 65,451$ & $\$ 80,735$ & $\$ 118,194$ & $\$ 165,467$ & $\$ 205,945$ & $\$ 209,240 \mid$ & $\$ 209,450$ & $\$ 209,450$ & $\$ 21,222$ & NA & NA \\
\hline
\end{tabular}

\section{NOTES for Table 4:}

(a) The US Bureau Labor Statistics annual inflation rates (Reference 13) are used to normalize the costs to 2015 in order to compare costs shown. 
INL/EXT-16-40218

\section{Conclusions}

1. Historical RPS funding and cost information is not consistent in terms of how either is categorized by mission, by activity, by funding organization, by costing organization, or by time period (fiscal or calendar).

2. Costs for this analysis were categorized into two areas: development of the specific RTG technology, and production and deployment of an RTG. This latter category includes material costs for the flight components (including Pu-238 and FWPF); manufacturing of flight components; assembly, testing, and transport of the flight RTG(s); ground operations involving the RTG(s) through launch; nuclear safety analyses for the launch and for the facilities housing the RTG(s) during all phases of ground operations; NEPA analyses; and radiological contingency planning. Costs for two past successful flight missions using RTGs, Cassini and MSL, were analyzed. Then the costs were normalized from the actual year costs to constant dollars in 2015 using historical escalation factors. This analysis results in a fairly similar 2015 normalized cost for the production and deployment of an RTG-approximately $\$ 118 \mathrm{M}$ for the GPHS-RTG and \$109M for the MMRTG. Note that the unit cost of the GPHS-RTG used for Cassini is based on simply dividing the total RTG production and deployment cost for the mission by the 3 units used for the mission. This reflects a lower cost per unit since some portion of the costs is divided equally among 3 units vs. 1 unit as in the case for MSL. In other words, there are certain sunk costs whether 1 RTG or 3 are involved.

3. Both of the RPS types analyzed herein use the general purpose heat source module as the "heart of the RPS." The estimates presented herein do not include development costs for the GPHS. These estimates also do not include the RPS infrastructure cost to maintain the facilities, equipment, and personnel necessary to enable the production of RPSs, except to the extent that the infrastructure is utilized during the production campaigns to provide RPSs for missions. It was not until after the Cassini mission that an RPS infrastructure funding structure defined and funded separately from mission-specific elements. The Pu-238 and FWPF costs for all three RTGs compared herein are based on the costs of these materials from Cassini, and then adjusted for the amount needed for each RTG, and normalized to 2015. 


\section{References}

1. Carl Friesen, personal communications, April 2016.

2. Hula, Greg, Atomic Power in Space II: A History of Space Nuclear Power and Propulsion in the United States, INL/EXT-15-34409, INL for DOE, September 2015.

3. "Final Technical Report GPHS-RTGs for the Cassini Mission," Lockheed Martin Document No. RR18, August 1998.

4. "Report on Audit of Funding for Advanced Radioisotope Power Systems," DOE/IG-0413, October 1997.

5. "Confirmation of Costs to Sustain RTG Production Capability," Pu-238 Facilities Review Team Report, March 1996.

6. "Agreement No. 1 to Supplement Memorandum of Understanding Dated July 26, 1991 Between the US DOE and NASA Concerning Radioisotope Power Systems for Space Missions," approved $11 / 9 / 93$.

7. Tim George, LANL, personal communication, April 2016.

8. Ryan Bechtel, DOE, personal communications, March 2016.

9. Ed Howell, Tech-Source, personal communication, April 2016.

10. Dirk Cairnes-Gallimore, DOE, personal communication, December 2015.

11. Rocketdyne End of Year Reports for MMRTG, October 2004-2012.

12. Idaho National Laboratory Monthly Earned Value Reports, MMRTG, October 2005-2015.

13. US Bureau of Labor Statistics, Annual Inflation Rates: http://www.bls.gov/cpi/tables.htm. 